\title{
Optimal scheduling of a renewable micro-grid in an isolated load area using mixed-integer linear programming
}

\author{
Hugo Morais, Péter Kádár, Pedro Faria, Zita A. Vale, H.M. Khodr
}

\begin{abstract}
A B S T R A C T
In the energy management of the isolated operation of small power system, the economic scheduling of the generation units is a crucial problem. Applying right timing can maximize the performance of the supply. The optimal operation of a wind turbine, a solar unit, a fuel cell and a storage battery is searched by a mixed-integer linear programming implemented in General Algebraic Modeling Systems (GAMS). A Virtual Power Producer (VPP) can optimal operate the generation units, assured the good functioning of equipment, including the maintenance, operation cost and the generation measurement and control. A central control at system allows a VPP to manage the optimal generation and their load control. The application of methodology to a real case study in Budapest Tech, demonstrates the effectiveness of this method to solve the optimal isolated dispatch of the DC micro-grid renewable energy park. The problem has been converged in $0.09 \mathrm{~s}$ and 30 iterations.
\end{abstract}

Keywords:

Mixed-integer linear programming

Renewable energy park

Scheduling

Virtual power producer

\section{Introduction}

Keeping the balance between load and generation is the basic rule of all power systems. In the autonomous power supply systems, as spacecrafts, airplanes or small islands, the critical amount of fuel and specific program of the generation capability give the scheduling problem special importance.

In the power system the daily load curve can be well forecasted. The forecast is based on statistical, analytical or technological models.

Characteristics of the system elements:

- Load - The power system contains controlled and uncontrolled loads. The time curve can be well forecasted.

- Generator - The generators have many constraints that are minimal/maximal capacity, fuel amount (total generated energy) and speedup ratio.

- Storage - A large amount of electricity can't be stored economically. Only small systems use super condensers and batteries, the greater systems contain pumped water storage, pressurized air, hydrogen generator, etc. The storage units have double characteristics: these are loads with limited capabilities, and later they may turn into generators. Due to the losses of transformation the storage has never $100 \%$ efficiency.

The scheduling problem exists in all power systems [1]. In the autonomous isolated renewable power systems and in the isolated micro-grids for the limited power source, the dynamic portfolio management is really important.

Nowadays there is an upward tendency for using small isolated power systems, against central power producing system when regarding rural and distant places [2].

In this type of system the most important producers are the renewable sources of energy (e.g, photovoltaic panels (PV), fuel cells, wind turbine, etc.) in combination with diesel generators. These small power producing networks need a distributed and autonomous power generation control [3-4].

Interest in small isolated power systems is also attractive for power utility companies, since they can help in improving the power quality and power supply flexibility. Also, they can provide spinning reserve and reduce the transmission and distribution costs, and can be used to feed the customers in the event of an outage in the primary substation [5].

Although the advantages of using small power systems are considerable, the systems that subsist only from a unique renewable energy source, have their differences because if the source considered is wind power it has more availability than one using photovoltaic panels. Adding storage capability increases the availability more for solar-based systems [6]. 


\section{VPP operation}

The aggregation of DG plants gives place to a new concept: the Virtual Power Producer (VPP). VPPs are multi-technology and multi-site heterogeneous entities. In the scope of a VPP, producers can make sure their generators are optimally operated. At the same time, VPPs will be able to commit to a more robust generation profile, raising the value of non-dispatched generation technologies [7].

The VPP can also operate in isolated networks. In this type of installation the VPP can detain the system management and equipment functioning responsibility.

VPP can reduce maintenance and operation costs of the isolated system and increase its efficiency.

The system management is made at distance, providing the possibility of controlling the aggregated producer's generation that is connected to the network and at the same time all the isolated power system (generation and consumption) [8]. It's possible to manage several isolated grids at the same time.

This type of management has many particular specifications, implying some adjustments to the VPP.

One of the differences is the aggregation goal. The "normal" VPP was as primary goal combine the generation of aggregated producers to sell the biggest quantity of energy in the market, to remunerate the producers and profit to it self. When VPP is managing isolated grids the most important goal is to deliver the necessary energy to assure the optimal function of loads. Therefore, it's necessary to manage the reserves and good operation of controllable generation units (fuel cells and micro-turbines).

Other important aspect that VPP has to consider in the isolated grids is the need to control the generation and the consumption. Since the system is isolated, some times, VPP has to disconnect some loads, to maintain the system balance, when the generation isn't enough.

The VPP can develop DSM (Demand Side Management) strategies to advert the users of the problems that can arise because of wrong electric energy usage.

In isolated grids, the VPP has control of all the system, therefore has to have voltage and frequency control methods and mechanisms that permits to adjust these parameters to obtain an adequate quality service to the consumers demands.

The existence of many isolated grids, that are geographically near and that are managed by the same VPP, can provide an interconnection of these systems, increasing more resources, dimension and stability for all systems [9].

The associated costs of these interconnections are proportional to the distance between grids, being an important restrain to this type of application. These interactions have to be done in MV to maintain a good voltage level and to reduce the transmission losses.

These installations can be useful to develop strategies and methodologies for VPP use, where there is the possibility of island actuation in incident situations, considering the of active networks utilization.

\section{Budapest Tech equipment}

In the Budapest Tech exists a small renewable system that has a wind turbine, photovoltaic panels and a fuel cell. The test system is implemented at the roof [10] (Fig. 1).

The equipment of generation has the following characteristics:

- Photovoltaic panel(s) - type: DS 40; Nominal power: $40 \mathrm{~W}$; Expected production of 4 panels $150 \mathrm{~W}$ peak

- Wind turbine - type: Air-X 401; Nominal power: $400 \mathrm{~W}$ at $11.5 \mathrm{~m} / \mathrm{s}$; Daily production (day and night) approx. $800 \mathrm{Wh}$

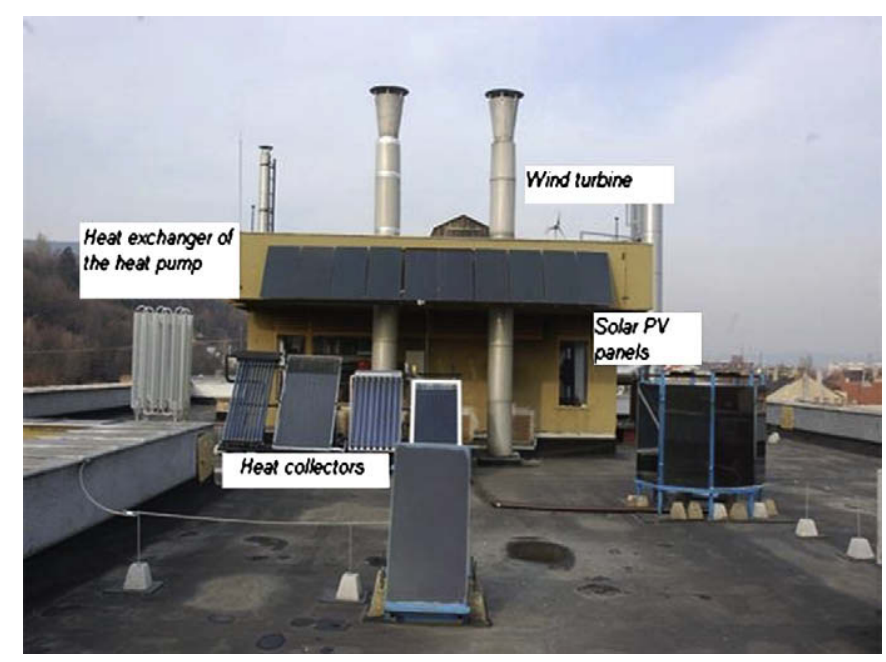

Fig. 1. Budapest Tech renewable system.

- Fuel cell - type: Flexiva; Nominal power: $80 \mathrm{~W}$

- Load - Practically lighting bulbs; Nominal power: 20-100 W (controllable)

- Storage - Storage maximum charging capacity: 200 W; Storage maximal discharging capacity: $50 \mathrm{~W}$

Many of them generate power in the form of direct current (e.g. $\mathrm{PV}$, fuel cells) or in the form of alternate current at a different frequency from the required $50 \mathrm{~Hz}$ (e.g. wind generators, microturbine). Therefore, the system containing these sources requires a power electronic interface. The system can be represented with the following scheme (Fig. 2).

The system can be operated connected to grid or in isolated system. In both situations, the control of all equipment is done with a centralized system for measurement and control. With this control system, it's possible to measure the generated energy by the wind turbine, photovoltaic panels, fuel cell, storage discharging and the energy consumed by the load. With the central control is possible regulate the fuel cell, the storage and the load, for balancing the system in according with the defined strategy [11].

It's also possible compare the forecast values of wind turbine and photovoltaic panels generation with the real values. This possibility allows a better system management.

The generation capability of the different units will be on-line monitored, and remotely switched by the scheduler.

When there is unbalance between active power generation and active power load demand, the frequency deviates from its nominal value. Therefore, the isolated system should be able to maintain frequency in an acceptable operating range to ensure power quality [12].

In a further extension the remote switches will be realized on IP base, so the physical micro-grid will be extended to virtual microgrid (Fig. 3).

\section{Problem formulation}

For the formulation of the problem we take a real case of the Budapest Tech system and develop a VPP operation in the isolated grid as following structure. Fig. 4 presents the structure of real case study system.

For the optimal operation system, the VPP same information needs, to define the amount of energy generated by wind energy, photovoltaic energy, fuel cell and the storage battery charging and discharging taking into account the following considerations: 


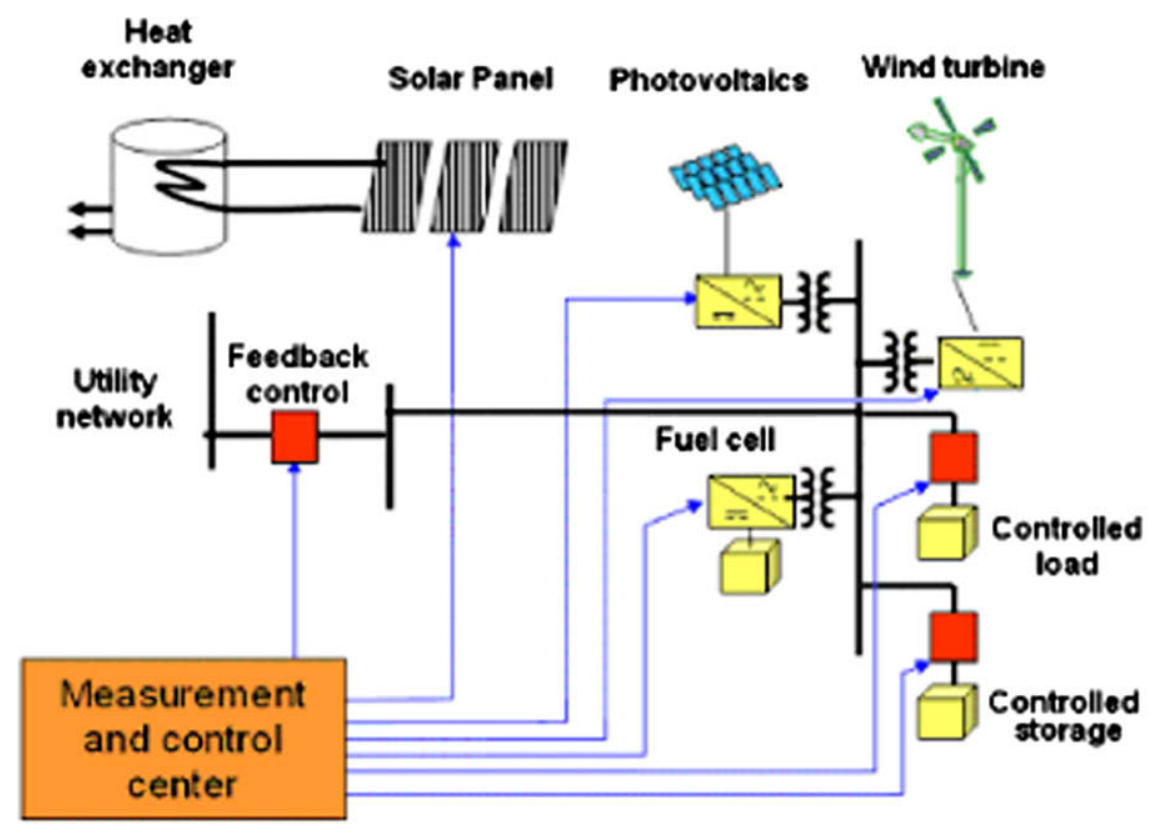

Fig. 2. Control of Budapest Tech renewable system.

- The wind power generation strongly depends on the weather. The generation capability can be estimated for a period of $24 \mathrm{~h}$ in advance. The wind energy is dispatched during the period due to it's cost;

- The photovoltaic generation can be well forecasted, too;

- The fuel cell has limited output for a long time, but the total generated energy is determined by the amount of the hydrogen fuel;

- The storage discharging is limited for a maximal discharging capacity and existing storage energy;

- The loads are forecasted considering several aspects, however the most of the loads can be controlled between limits (this is the DSM - Demand Side Management);

- To system balance, the VPP can settle terms of reserve. For example the VPP can limit the minimum reserve to the $10 \%$ of load forecast. This reserve can be assured by storage and fuel cell.

Our objective is carrying out an optimal dispatch taking into account all mentioned considerations.

The expected result will be the following priorities: 1st - wind, 2nd - photovoltaic, 3rd - Fuel cell (if it is necessary). The surplus energy is used for charging the storage battery capacity. The different units have different costs, as well. The wind and solar energy are "free", or without cost. The storage energy has being limited; the hydrogen-based fuel cells have expensive cost and limited capacity. It is only the emergency reserve.

This continuous constrained portfolio problem is solved by CPLEX in GAMS platform [13], but the problem can be solved by other optimization software package.

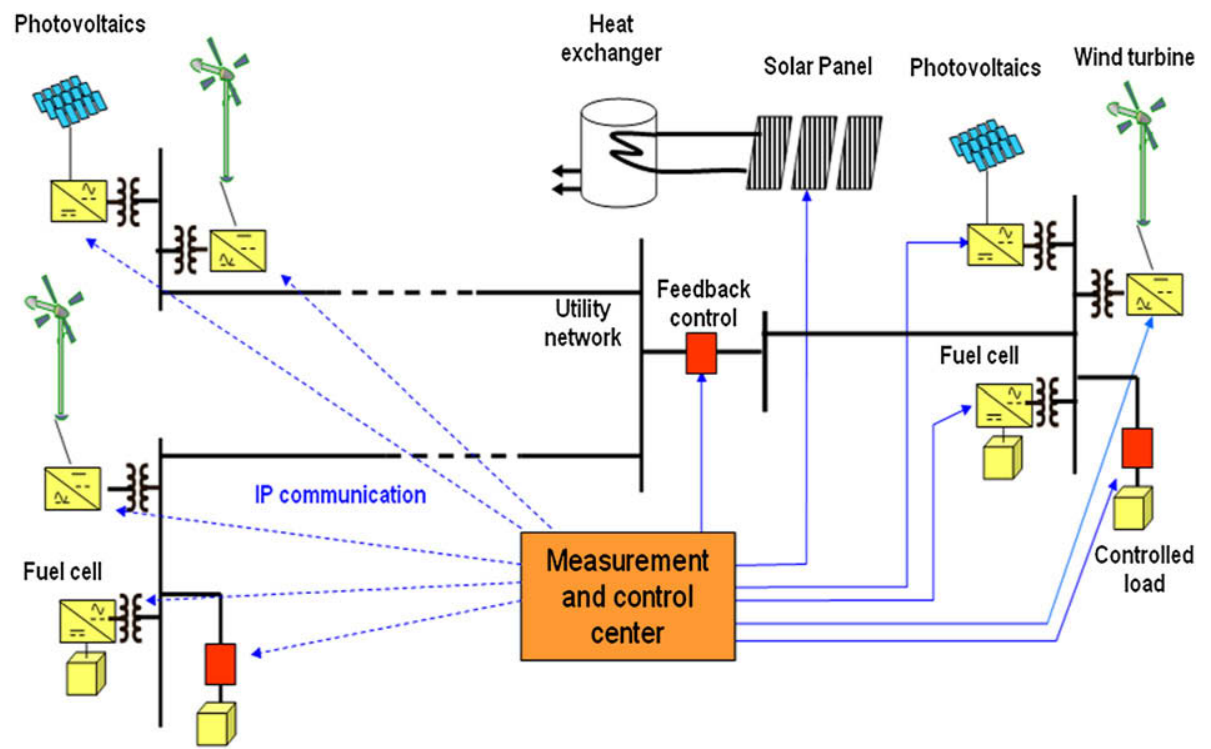

Fig. 3. Virtual micro-grid control. 


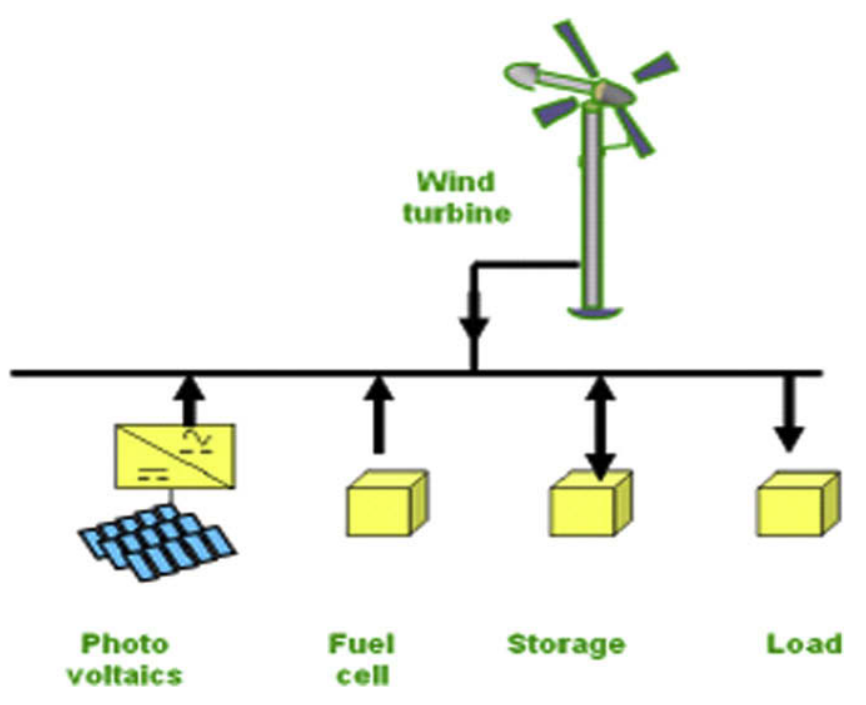

Fig. 4. Budapest Tech isolated system.

The optimal schedule of the demand and generator can be made for $5 \mathrm{~min}, 1 \mathrm{~h}, 1$ day or for 1 week. It's depending on the load forecast, for wind and photovoltaic energy generation forecast.

The constraint of the problem has been elaborated taking considering the five different operation modes:

1. There is surplus energy to store (for more details see Fig. 5).

2. The primary generation is not enough therefore the battery is discharged. In this problem we considered $40 \%$.

3. In lack case of primary generation (no wind and/or sunshine) the battery and Fuel Cell come into operation (see Fig. 6).

4. In storage lack case energy only Fuel Cell comes into operation.

5. In unsatisfactory energy generation case the load must be shed.

The objective function of the mixed-integer linear model is to find the total minimal marginal cost for a period of $24 \mathrm{~h}$.

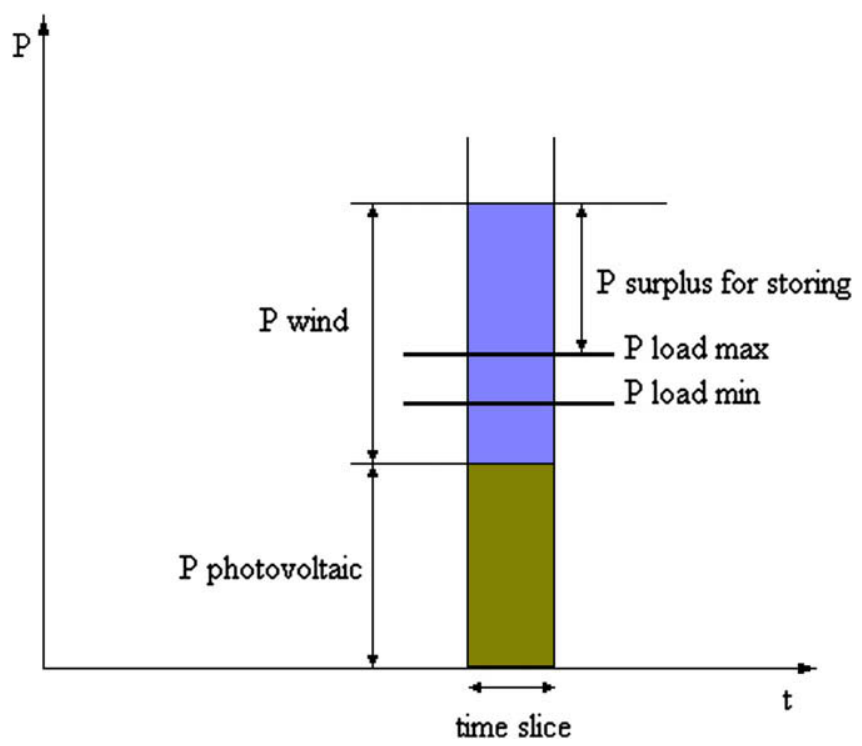

Fig. 5. Surplus of primary energy.

4. Fuel Cell limits in each period " $t$ "

$P_{\text {Fuel Cell }(t)} \leq 80 \mathrm{~W} ; \quad t \in\{1, \ldots, 24\}$

5. Storage battery limits in each period " $t$ "

$P_{\text {Storage }(t)} \leq 200 \mathrm{~W} ; \quad t \in\{1, \ldots, 24\}$

6. Storage battery maximal discharge limits in each period " $t$ "

$P_{\text {Storage Battery Discharge }(t)} \leq 50 X_{(t)} ; \quad t \in\{1, \ldots, 24\} ; \quad X \in\{0,1\}$

7. Storage battery maximal charge limits in each period " $t$ "

$P_{\text {Storage Battery Charge }(t)} \leq 200 Y_{(t)} ; \quad t \in\{1, \ldots, 24\} ; Y \in\{0,1\}$

$\operatorname{Minimize~} f=\operatorname{Min}\left[\sum_{t=1}^{24}\left(\begin{array}{r}P_{\text {Wind }(t)} \times c_{\text {Wind }(t)}+P_{\text {Photovoltaic }} \times c_{\text {Photovoltaic }(t)} \\ +P_{\text {Fuel Cell }(t)} \times c_{\text {Fuel Cell }(t)} \\ -P_{\text {Storage Batery Charge }(t)} \times c_{\text {Storage Batery Charge }(t)} \\ +P_{\text {Storage Batery Discharge }(t)} \times c_{\text {Storage Batery Discharge }(t)} \\ + \text { Undelivered Energy }(t) \times C_{\text {Undelivered Energy }(t)} \\ \text {-Excess Generated Energy }(t) \times c_{\text {Excess Generated Energy }(t)}\end{array}\right)\right]$

Subject to a following constraints:

1. First Kirchhoff Law or Power Balance

$\sum_{t=1}^{24}\left(\begin{array}{c}P_{\text {Wind }(t)}+P_{\text {Photovoltaic }(t)}+P_{\text {Fuel Cell }(t)} \\ +P_{\text {Storage Batery Discharge }(t)}+\text { Undelivered Energy }(t)= \\ =\operatorname{Load}_{(t)}+P_{\text {Storage Batery Charge }(t)}+\text { Excess Generated Energy }(t)\end{array}\right)$

2. Wind generation limits in each period " $t$ "

$P_{\text {Wind }(t)} \leq P_{\text {Wind Limit }(t)} ; \quad t \in\{1, \ldots, 24\}$

3. Photovoltaic generation limits in each period " $t$ "

$P_{\text {Photovoltaic }(t)} \leq P_{\text {Photovoltaic Limit }(t)} ; \quad t \in\{1, \ldots, 24\}$
8. The battery can't charge and discharge at the same time in each time slice " $t$ "

$X_{(t)}+Y_{(t)} \leq 1 ; \quad t \in\{1, \ldots, 24\} ; X$ and $Y \in\{0,1\}$

9. Storage battery maximal discharge limits in each period " $t$ " considering the battery state storage in period $t-1$ 


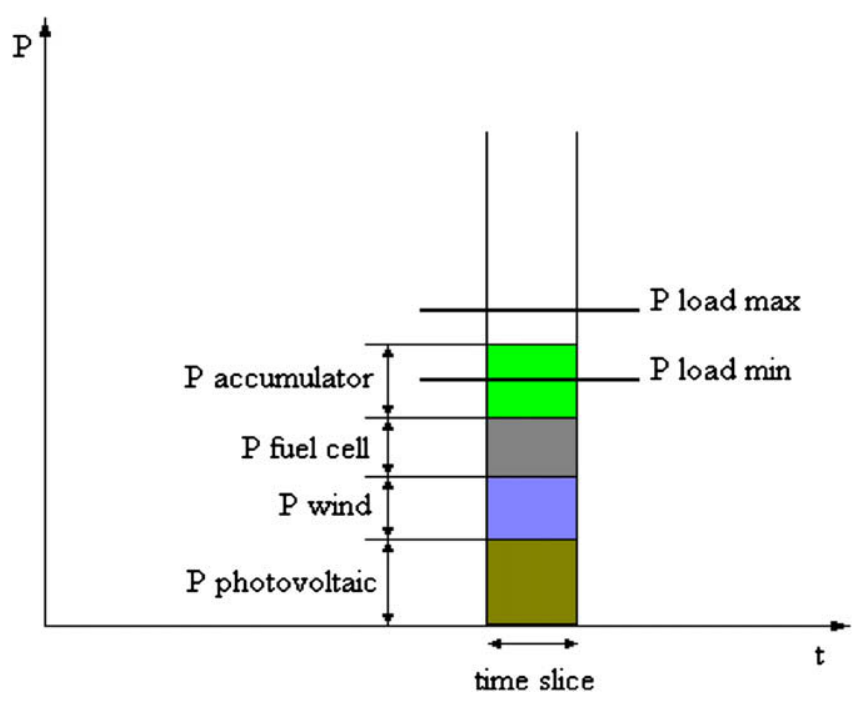

Fig. 6. The storage and the fuel cell are in operation.

$P_{\text {Storage Battery Discharge }(t)}-P_{\text {Storage Battery }(t-1)} \leq 0$;

$$
t \in\{1, \ldots, 24\} ;
$$

10. Storage battery maximal charge limits in each period " $t$ " considering the battery state storage in period $t-1$

$P_{\text {Storage Battery Charge }(t)}+P_{\text {Storage Battery }(t-1)} \leq 200 \mathrm{~W}$;

$$
t \in\{1, \ldots, 24\} \text {; }
$$

11. State balance of battery

$P_{\text {Storage Battery }(t)}=P_{\text {Storage Battery }(t-1)}-P_{\text {Storage Battery Discharge }(t)}$

$$
+P_{\text {Storage Battery Charge }(t)} ; \quad t \in\{1, \ldots, 24\} ;
$$

12. Initial state of the battery

$P_{\text {Storage Battery }(t=0)}=100 \mathrm{~W}$

\begin{tabular}{|c|c|c|c|c|c|c|c|c|}
\hline \multirow[t]{2}{*}{$i$} & \multicolumn{6}{|c|}{ All scenarios } & \multirow{2}{*}{$\frac{\text { Scen. } 1}{L}$} & \multirow{2}{*}{$\frac{\text { Scen. } 2}{L}$} \\
\hline & $P_{\mathrm{W}}$ & $P_{\mathrm{V}}$ & $P_{\mathrm{F}}$ & $P_{S-1}$ & $P_{\mathrm{SC}}$ & $P_{\mathrm{SD}}$ & & \\
\hline 1 & 130 & 0 & & & & & 160 & 230 \\
\hline 2 & 150 & 0 & & & & & 140 & 190 \\
\hline 3 & 140 & 0 & & & & & 150 & 160 \\
\hline 4 & 160 & 0 & & & & & 120 & 150 \\
\hline 5 & 100 & 0 & & & & & 110 & 140 \\
\hline 6 & 120 & 5 & & & & & 100 & 180 \\
\hline 1 & 150 & 10 & & & & & 170 & 230 \\
\hline 2 & 180 & 30 & & & & & 180 & 250 \\
\hline 3 & 170 & 60 & & & & & 200 & 270 \\
\hline 4 & 160 & 100 & & & & & 220 & 280 \\
\hline 5 & 120 & 130 & & & & & 230 & 240 \\
\hline 6 & 130 & 140 & $\leq 80$ & 100 & $\leq 200$ & $\leq 50$ & 240 & 300 \\
\hline 1 & 150 & 150 & & & & & 240 & 300 \\
\hline 2 & 176 & 140 & & & & & 230 & 280 \\
\hline 3 & 185 & 130 & & & & & 220 & 270 \\
\hline 4 & 120 & 100 & & & & & 210 & 280 \\
\hline 5 & 130 & 60 & & & & & 210 & 290 \\
\hline 6 & 140 & 30 & & & & & 220 & 300 \\
\hline 1 & 170 & 10 & & & & & 230 & 310 \\
\hline 2 & 190 & 5 & & & & & 240 & 320 \\
\hline 3 & 120 & 0 & & & & & 250 & 330 \\
\hline 4 & 170 & 0 & & & & & 200 & 300 \\
\hline 5 & 130 & 0 & & & & & 190 & 280 \\
\hline 6 & 150 & 0 & & & & & 180 & 270 \\
\hline
\end{tabular}

Table 1

Scenarios of generation/consumption.

All values are given in $\mathrm{Wh}$.

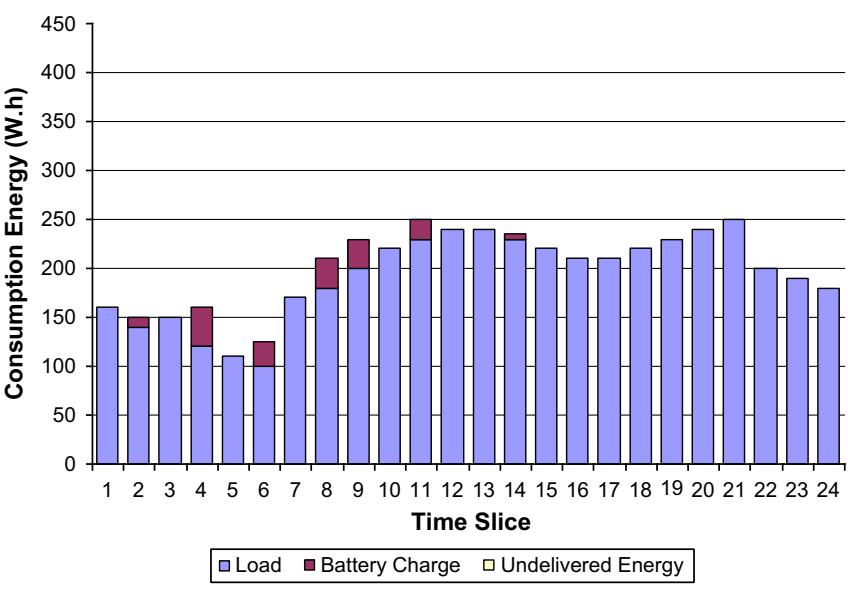

Fig. 7. Energy consumption in scenario.

For the succeeding time slices the constraints are the same. The existent storage energy is updated between time slices. If considered a large number of time slices, it's possible to minimize the operation costs and optimize the storage management.

\section{Case study}

For the application of the methodology we developed a digital program GAMS [13], where has been applied to real case corresponding to Budapest Tech Renewable Equipment in Hungary. The considered prices are the following: Wind energy $0.4 € / \mathrm{kWh}$; photovoltaic $0.4 € / \mathrm{kWh}$; fuel cell $0.9 € / \mathrm{kWh}$; storage discharging $0.6 € / \mathrm{kWh}$; storage charging $0.4 € / \mathrm{kWh}$; undelivered power is $1.5 € / \mathrm{kWh}$ and the excess energy is $0 € / \mathrm{kWh}$.

To illustrate the generality and the effectiveness of a proposed methodology we implemented a scenario with different increased load shown in Table 1.

The simulation considerers the technical characteristics of Budapest Tech equipment and has analyzed for $24 \mathrm{~h}$ period sequential time.

To order to scheduling the generation units, we establish a cost of generation for each technology.

In these scenarios we obtain some important results as well as the optimal renewable energy dispatch taking into account the marginal cost of each generation technology.

Fig. 7 represents the scenario that the entire loads are satisfied, but in the intervals time $2,4,6,8,9$ and 14 , we can appreciate the battery charging.

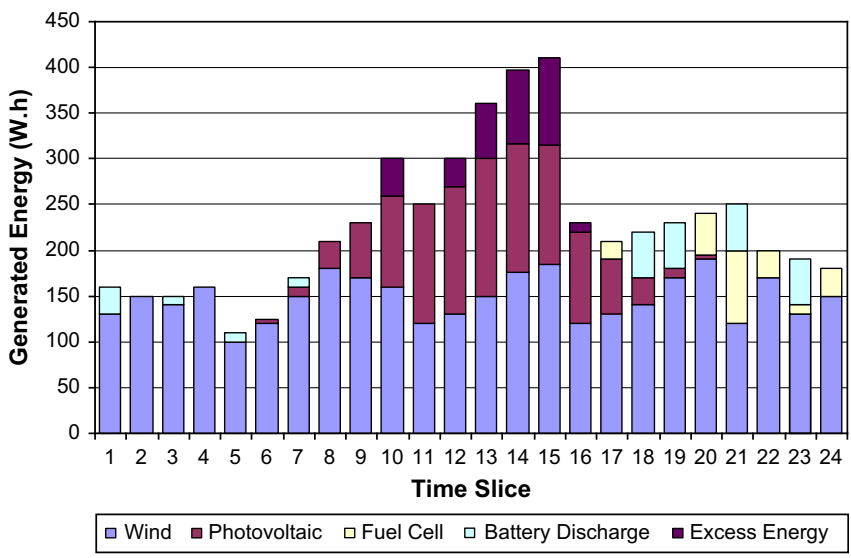

Fig. 8. Generation and consumption energy in scenario 2 . 


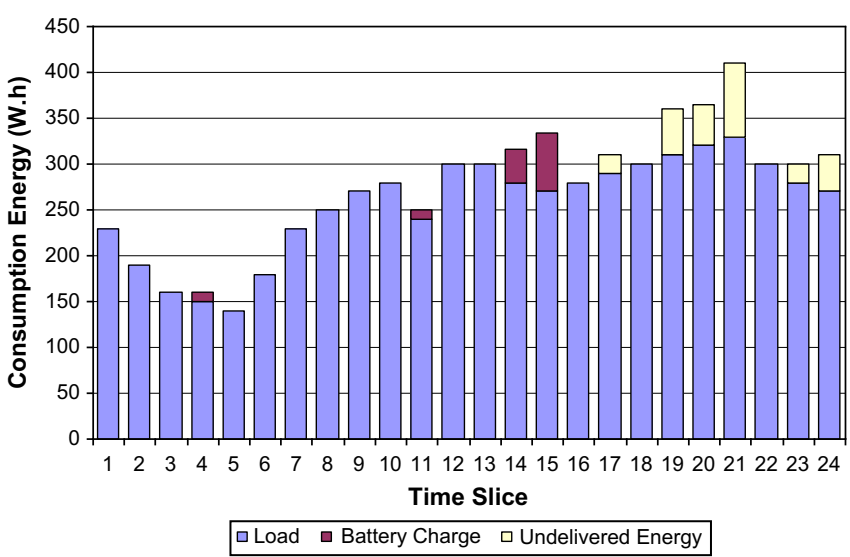

Fig. 9. Generation and consumption energy in scenario 2 .

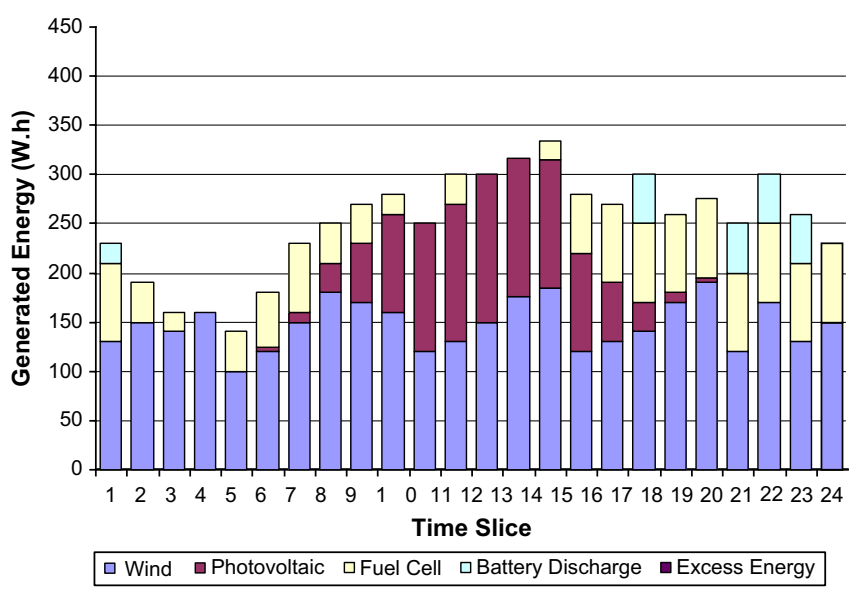

Fig. 10. Generation and consumption energy in scenario 2.

In Fig. 8 we can show the optimal generating scheduling. In the intervals time of one hour $1,3,5,7,18,19,21$ and 23, we can appreciate the battery discharging.

During the interval time of $10,12,13,14,15$ and 16 the excess generated energy has been represented.

Fig. 9 presents the optimal dispatch scenario, where the battery charges only in the intervals $4,11,14$ and 15 respectively. In this scenario we have a part of load that it is not served due to the cost of the generated energy, the undelivered energy is presented in the interval time of $17,19,20,21,23$ and 24 respectively.

Fig. 10 presents another scenario where we consider the load is very high, that is represented in Table 1.

In this scenario, the wind energy, photovoltaic, the fuel cells are dispatched in the majority of the time considered intervals. The battery is discharged in a few time interval as well as the $1,18,21,22$ and 23 respectively.

\section{Conclusion}

In this paper we presented the optimal operation of an isolated system by a VPP. The main goal is to decide the best VPP management strategy to minimize the generation costs and optimize storage charging and discharging time subjected to all the operation technical constraints.

The dispatch has been formulated as a mixed-integer linear programming problem and solved by the developed program elaborated in GAMS Platform using CPLEX.

The VPP must control of all system to balance the generation and the consumption in each interval time of one during a period of one day.

The application of the methodology to a real case presented in Budapest Tech, demonstrates the effectiveness, and the robustness of the proposal. It is also verified that have a very low execution time for solving a mixed-integer linear programming problem. The proposed method can help the planner engineer to minimize the operation cost of the generations units taking into account the reliability expressed in the undelivered energy.

\section{Acknowledgments}

The authors would like to acknowledge FCT, FEDER, POCTI, POSI, POCI and POSC for their support to R\&D Projects and GECAD Unit.

\section{References}

[1] El-Khattam W, Bhattacharya K, Hegazy Y, Salama MMA. Optimal investment planning for distributed generation in a Competitive electricity market. IEEE Transactions on Power Systems August 2004;19(3):1674-84.

[2] Praça I, Ramos C, Vale Z, Cordeiro M. MASCEM: a multiagent system that simulates competitive electricity markets. IEEE Intelligent Systems Nov-Dec 2003;18(6):54-60.

[3] IEA, International Energy Agency. Distributed generation in liberalised electricity markets; 2002.

[4] Bertani A, Bossi C, Fornari F, Massucco S, Spelta S, Tivegna F. A microturbine generation system for grid connected and islanding operation. In: Power systems conference and exposition, 2004. IEEE PES, vol. 1; 10-13 October 2004. p. 360-5.

[5] Milošević M. Andersson G. Generation control in small isolated power systems. In: 37th annual north American power symposium; 2005.

[6] Hatziargyriou Nikos, Meliopoulos Sakis. Distributed energy sources: technical challenges. In: Power engineering society winter meeting, 2002. IEEE, vol. 2; 27-31 January 2002. p. 1017-22.

[7] Morais Hugo, Cardoso Marílio, Castanheira Luís, Vale Zita, Praça Isabel. A decision-support simulation tool for virtual power producers. In: International conference on future power systems; 2005.

[8] Oxera, OXERA Consulting Ltd. Electricity liberalisation - indicators in Europe; 2001.

[9] Consentec, Frontier Economics. Benefits and practical steps towards the integration of intraday electricity markets and balancing mechanisms; 2005.

[10] Kádár Péter. Energy on the roof. In: 3rd Romanian-Hungarian joint symposium on applied computational intelligence - SACI proceedings; May 25-26, 2006 [Timisoara, Romania], p. 343-52.

[11] Ferenc Herbert. Magyarország els folyamatosan hálózatra termel mini naper_mve. Elektrotechnika 2004;7-8:232-3 [in Hungarian].

[12] Roland Süt. A napelem cellák vizsgálatának kutatási eredményei. Elektrotechnika 2006;2:8-9 [in Hungarian].

[13] GAMS Development Corporation, Washington, DC 20007, USA. GAMS - the solver manuals, GAMS user notes; January 2001. 